Benha Veterinary Medical Journal 41 (2021) 42-44

Benha Veterinary Medical Journal
Official Journal Issued by
Faculty of
veterinary Medicine $\quad$ Journal homepage: https://bvmj.journals.ekb.eg/

Original Paper

\title{
Isolation and identification of non-cytopathic strain of bovine viral diarrhoea virus from ovaries of Egyptian heifer and cow in 2019
}

\author{
Zeinab R.A. Aboezz ${ }^{1}$, Samia A. Elnagar ${ }^{2 *}$, Rania S.A.El-Mohamady ${ }^{2}$, Ayman S. El-Habbaa ${ }^{1}$, Ehab M. El- \\ Nahas $^{1}$ \\ ${ }^{I}$ Department of Virology, Faculty of Veterinary Medicine, Benha University, Egypt \\ ${ }^{2}$ Animal Reproduction Research Institute (ARRI), Agricultural Research Center (ARC), Giza, Egypt
}

\section{ARTICLE INFO}

Keywords

non cytopathic $B V D V$

Ovaries

Genotype1

Isolation

$R T-P C R$

Received 05/06/2021

Accepted 21/06/2021

Available On-Line

$01 / 10 / 2021$

\section{INTRODUCTION}

Bovine viral diarrhoea virus (BVD) is a major pathogen that affects the entire world's ruminant population. It is a major source of economic concern (Krametter-Froetscher et al., 2010 and Chang et al., 2021). It is the major cattle pathogen that involved in reproductive concern (Fray et al., 2000). It is an enveloped virus belongs to family Flaviviridae, genus Pestivirus. It has positive-sense, singlestranded RNA and $12.3 \mathrm{~kb}$ long. BVDV is divided into two genotypes: BVDV-1 and BVDV-2, while another pestivirus species "HoBi-like "could be considered as BVDV-3 genotype (Gomez-Romero et al., 2017, Bauermann and Ridpath, 2015). The 5' and 3' untranslated regions (5'UTR, $3^{\prime} \mathrm{UTR}$ ) flank the BVD genome. It is translated into a single polyprotein which is then cleaved into 11-12 structural and non-structural proteins (Npro, C, Erns, E1, E2, P7, NS2/3, NS4A, NS4B, NS5A, and NS4B). Based on its potential to produce noticeable effects on cell culture, BVDV can be categorised into two biotypes; cytopathic (CP) and noncytopathic (NCP). Virus isolation and detection by immune peroxidase technique and immune florescent assay is a golden method for BVDV in diagnostic procedures (Gao, et al., 2011, Bedeković et al., 2011). Moreover, RT-PCR is a valuable diagnostic tool that could determine the BVDV subtypes (Weinstock et al., 2001). In Egypt, BVDV infection is still causing great economic losses in cattle and buffaloes population in spite of vaccination programs (Elbagoury et al., 2012). The continuous circulation of virus in the field and quasi species nature of RNA genome raises new variants of virus (Domingo et al., 2003).

So, our study directed to word determination the circulating BVDV in Egypt in 2019 by viral isolation followed detection and identification that might help for design appropriate preventive measures including effective vaccination program.

\section{MATERIAL AND METHODS}

\subsection{Specimen collection}

Five ovaries were collected from freshly slaughtered heifers and cows from abattoirs in Beheira Governorate in the year 2019, with pervious history of reproductive problem as poor conception rate, early embryonic deaths and abortion. Ovarian sample were collected under complete aseptic condition. In addition; five serum samples were collected from the same animals. Serum samples were kept at $-20{ }^{\circ} \mathrm{C}$ for further isolation and identification.

\subsection{Processing of collected samples}

Each ovary was homogenized as one gram vortexed in $4 \mathrm{ml}$ of DMEM with penicillin (100 IU/ml), streptomycin (100 $\mathrm{mg} / \mathrm{ml})$, and amphotericin-B $(2.5 \mathrm{mg} / \mathrm{ml})$. After centrifugation, the homogenate was clarified, and the supernatant was collected and preserved at $-70{ }^{\circ} \mathrm{C}$ for further isolation and identification.

\subsection{Reference $B V D V$ strain and antiserum}

NADL strain is a cytopathic BVDV strain. It was propagated in MDBK cell line with a titre $10^{6.5} \mathrm{TCID} 50 / \mathrm{ml}$ and used as positive control in vial isolation, detection and identification by RT-PCR. BVDV polyclonal antiserum was used in viral detection by immune peroxidase technique (IPT) and immune florescent test (IFT). Rabbit Antibovine-IgG conjugated with fluorescienisothiocyanate were used in viral detection by (IFT) and goat anti bovine 
Peroxidase-labelled immune $\operatorname{IgG}$ for IPT. BVDV reference strain and antiserum were provided by the Department of virology, Animal Health Research Institute, Dokki, Giza, While the fluorescienisothiocyanate conjugate was supplied by Sigma.

\subsection{BVDV isolation on MDBK cells}

Prepared ovarian homogenate and serum were inoculated onto MDBK monolayer cultures. The MDBK cultures were examined for CPE for 6days. The cultures were frozen at $70^{\circ} \mathrm{C}$, then thawed and the supernatants were collected after centrifugation and stored at $-70^{\circ} \mathrm{C}$. Inoculated cultures were included as negative controls and inoculated NADL as positive control.

\subsection{Identification of $B V D V$ by IFT}

The inoculated cells with ovarian homogenate were detected by IFT proved by immune fluorescence (IFX) staining (Roberts et al., 1991)

\subsection{Extraction of $B V D V R N A$}

QIAamp ${ }^{\circledR}$ Viral RNA mini Kit (Qiagen, USA) was used to extract total RNA from the collected samples, according to the manufacturer's instructions. The extracted RNA was stored at $-80^{\circ} \mathrm{C}$ for further use

\subsection{Molecular identification of BVDV by RT-PCR}

One-Step RT-PCR Kit (Qiagen), was used to perform reverse transcription-polymerase chain reaction (RT-PCR) using specific primer set for 5 UTR gene. The sequence of oligonucleotides is: F 5'- ATGCCCWTAGTAG GACTAGCA - 3' (forward primer) R 5'TCAACTCCATGT GCCATGTAC - 3' (reverse primer) targeting 288bp sequence (Vilcek et al., 1994). The reaction conditions were $50^{\circ} \mathrm{C}$ for $30 \mathrm{~min}$ followed by $94^{\circ} \mathrm{C}$ for $7 \mathrm{~min}$; and 35 cycles of $94^{\circ} \mathrm{C}$ for $10 \mathrm{~min} 91 \mathrm{sec}$, $53^{\circ} \mathrm{C}$ for $30 \mathrm{sec}, 68{ }^{\circ} \mathrm{C}$ for $30 \mathrm{sec}$; and final elongation at $68^{\circ} \mathrm{C}$ for $7 \mathrm{~min}$. The PCR products analysis were performed on $1 \%$ agarose gel.

\section{RESULTS}

There was no cytopathic effect observed in the inoculated MDBK cells for 7days in comparing with control positive as in fig (1). but, There were 2 of 5 ovarian homogenate are positive by IFT fig (2) . This result was parallel to the result of serum samples as two of them were positive by IPT as positive serum showed red-brown cytoplasmic staining, as a positive result suggesting the presence of a noncytopathic BVD biotype as in fig (3).

The positively infected MDBK cell by IPT and IFT showed positive RT-PCR results, and the PCR products were at the predicted size, 288bp for 5 UTR of BVD-1, were observed as clear electrophoretic band it was similar to 1 was similar to reference NADL strain as fig (4)

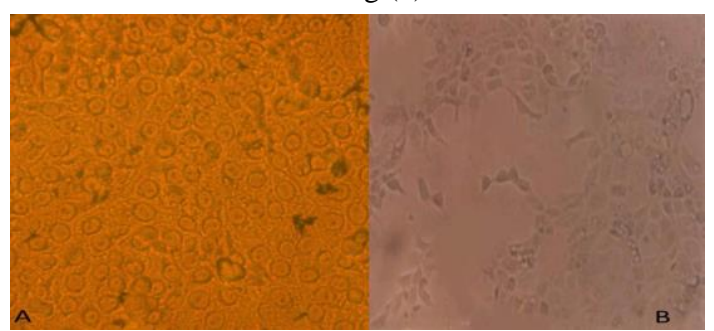

Fig. (1): Infected MDBK cell lines without CPE suggesting non-cytopathic biotypes of BVDV (A) compared with characteristic CPE of reference NADL strain in the form of cell rounding, aggregation, vacuolation followed by cellular darkness and cluster formation and cell detachment (B)

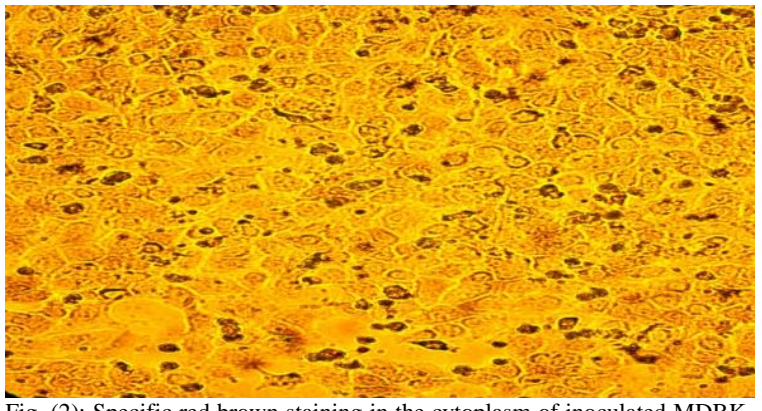

Fig. (2): Specific red brown staining in the cytoplasm of inoculated MDBKcell culture indicating presence of BVDV virus

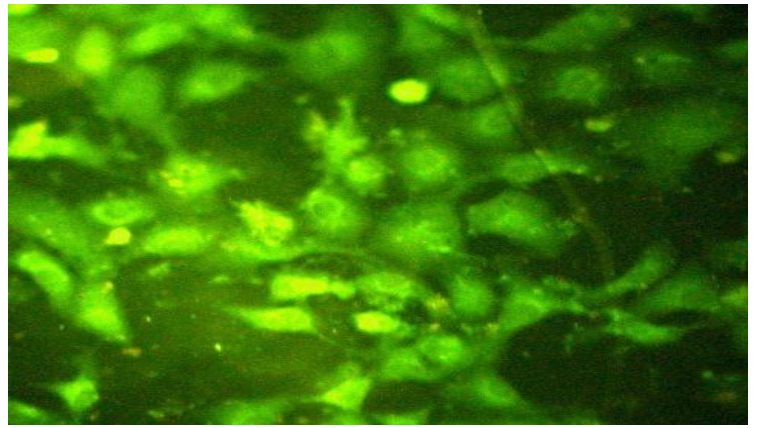

Fig. (3): Specific yellowish green fluorescent granules emitted from the inoculated MDBK- cell culture indicating presence of BVDV virus

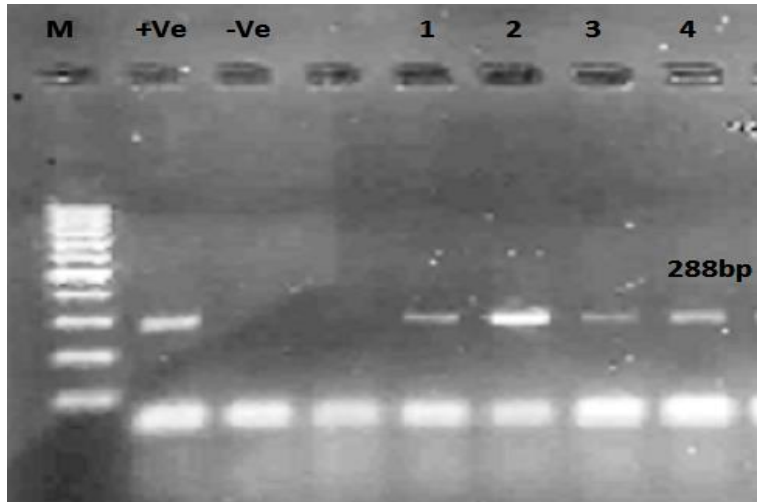

Fig. (3): Electrophoresis of the RT-PCR for BVDV isolate the amplified products are288bp from Bovine serum and ovaries. Lane M: molecular weight marker (100 bp), Lane +ve: RT-PCR reference NADL strain, Lane ve: negative control, lane $1,2,3 \& 4$ : Positive $288 \mathrm{bp}$ product of BVDV isolate

\section{DISCUSSION}

Bovine viral diarrhoea virus is responsible for several problems in cattle population as many reproductive concerns in cattle. The virus could be transmitted from cow to calf, resulting in abortion and the birth of deformed calves and/or persistently infected (PI) calf (Hause et al., 2021). Being an RNA virus, BVDV has a high mutation rate with unique pathogenesis and variability which make BVDV control is challenging (Chang et al., 2021). The standard method for detecting BVDV-infected cattle is virus isolation. BVDV-infected animals, particularly persistent infection (PI) animals, can release high levels of BVDV in their serum (Chang et al., 2021). So in this study serum samples and ovarian homogenate were used for viral isolation. MDBK cell line was suitable for BVDV isolation (Fulton et al., 2006). The presence or absence of observable CPE in infected cells divides BVDV into two biotypes (Ammari et al., 2010). Our BVDV isolate was non cytopathic biotype as it was not able to produce any cytopathogenic effect on MDBK cell in comparing with NADL strain that produce cell rounding, aggregation, 
vaculation and lastly cell darkness and cluster formation after 48 hours post inoculation. This result was agreeable with (Gao et al., 2011). Furthermore, non-cytopathic strain of BVD Could be detected by characteristic intracytoplasmic yellowish green fluorescence by IFAT (Goyal and Ridpath 2005) or by using IPT as the virus presence detected as red-brown cytoplasmic staining (Gao et al., 2011). Isolation of non-cytopathogenic BVDV enhances persistent infection of in cattle population (Ridpath et al., 2006; Gard et al., 2009). There are 2 common genotype of BVDV; BVD-1 which is the world widely prevalent while, BVDV-2 is less prevalent. Moreover; BVD-1 could be cytpopathic or non-cytopathic to cell culture (Ridpath, 2003). Several RT-PCR assays were used for identification and genotyping of BVDV (Chang et al., 2021, Mirosław and Polak, 2019). RT- PCR was an accurate and strong technique for detection and identification of BVDV (Weinstock et al., 2001). Our $\mathrm{BVDV}$ isolate was found to be a type $1 \mathrm{BVDV}$. as PCR product of (288 bp) was similar to reference NADL strain.

\section{CONCLUSION}

It is obvious from the obtained result that immune peroxidase technique and immune florescent assay is highly sensitive and specific tool for detection of cytopathic and non- cytopathic BVDV; More over RT-PCR is a highly sensitive tool for genotyping of BVDV. Further molecular analysis is recommended to confirm these finding and determine the molecular epidemiology of BVD-1 isolate and update the nature of the future vaccine for successful preventive strategies.

\section{CONFLICT OF INTEREST}

The authors declare that they have no conflicts of interest for current data

\section{REFERENCES}

1. Ammari. M.; McCarthy, F.M.; Nanduri, B.; Pinchuk. L.M. 2010. Analysis of Bovine Viral Diarrhea Viruses-infected monocytes: identification of cytopathic and non-cytopathic biotype differences. BMC Bioinformatics.; 11(Suppl 6): S9.

2. Bauermann,F.V.; Ridpath, J.F.2015. HoBi-like viruses--the typical 'atypical bovine pestivirus'. Anim Health Res Rev.;16(1):64-9.

3. Bedeković, T.; Lemo, N.; Lojkić, I.; Cvetnić, Z.; Cač, Z., Madić, J. 2011 Development of an indirect immunofluorescence assay for diagnosis of bovine viral diarrhoea virus on ear notch tissue samples in cattle infected persistently. J Virol Methods. 178(1-2):59-62.

4. Chang. L.;Qi, Y.; Liu, D.; Du, Q.; Zhao, X. ;Tong, D. 2021Molecular detection and genotyping of bovine viral diarrhea virus in Western China. BMC Veterinary Research. Feb;17(1):66.

5. Domingo, E., Escarmis C., E.Baranowsk, C.M. Ruiz-Jarabo, E. Carrillo, J.I. Nunez and C.M. Ruiz-Jarabo, and Sobrino F.,
2003. Evolution of foot-and-mouth disease virus, Virus research, 91: 47-56.

6. El-Bagoury, G.F.; El-Nahas, E.M.; Khadr, K.A. and Nawal M. Ali. 2012 Isolation and genotyping of bovine viral diarrhea virus field isolates from infected cattle in Kaluobia during 2011. Benha veterinary medical journal, 23(I): 6-10.

7. Fray, M.D., Mann, G.E., Clarke, M.C., Charleston, B. 2000 Bovine viral diarrhoea virus: its effects on ovarian function in the cow. Vet Microbiol. 15;77(1-2):185-94.

8. Fulton, R.W., Hessman, B., Johnson, B.J., Ridpath, J.F., Saliki, J.T., 2006. Evaluation of diagnostic tests used for detection of bovine viral diarrhea virus and prevalence of subtypes $1 \mathrm{a}, 1 \mathrm{~b}$, and $2 \mathrm{a}$ in persistently infected cattle entering a feedlot. J. Am. Vet. Med. Assoc. 228, 578-584.

9. Gao, Y.; Wang, S.; Du, R.; Wang, Q.; Sun, C.; Wang, N.; Zhang, P.; \& Zhang, L. 2011. Isolation and identification of a bovine viral diarrhea virus from sika deer in china. Virology journal, 8:83. doi:10.1186/1743-422x-8-83

10. Gard, J.A., Givens, M.D., Marley, M.S., Galik, P.K., Riddell, K.P., Stringfellow, D.A., Zhang, Y., Edmondson, M.A., 2009. Bovine viral diarrhea virus (BVDV) associated with single in vivo-derived and in vitro-produced preimplantationbovineembryos following artificial exposure. Theriogenology 71, 1238-1244.

11. Gomez-Romero, N.;Basurto-Alcantara, F.J.; VerdugoRodriguez, A.;Bauermann, F.V.; Ridpath, J.F. 2017 . Genetic diversity of bovine viral diarrhea virus in cattle from Mexico. J Vet DiagnInvestig. 2017;29(3):362-365.

12. Goyal, S.M. and Ridpath, J.F. 2005. Bovine viral diarrhea virus diagnosis, management, and control 1 sted, 2005. Ames, Iowa: Blackwell.

13. Hause, B. M.; Ridpath, J. F.; Pillatzki, A.E.; Bragg, T.and Chase, C.C.L. 2021.The Presence of Persistent Bovine Viral Diarrhea Virus Infection and a Novel Bosavirus in a Bison Herd SDSU Beef Day 2021 Summary Publication. 8.

14. Krametter-Froetscher, R.; Duenser, M.; Preyler, B.; Theiner, A.; Benetka, V.; Moestl, K.; Baumgartner,W .2010 Pestivirus infection in sheep and goats in West Austria. Vet J. 186(3):342-346

15. Meyling, A. 1984. Detection of BVD virus in viremic cattle by an indirect immunoperoxidase technique. pp. 37-46.

16. Mirosław,P. and Polak ,M. 2019 Increased genetic variation of bovine viral diarrhea virus in dairy cattle in Poland Veterinary Research; 15(1),278.doi:10.1186/s12917-019-2029

17. Ridpath JF. 2003. BVDV genotypes and biotypes:Practical implications for diagnosis and control. Biologicals 31:127131.

18. Ridpath, J.F.; Bendfeldt, S.; Neill, J.D. and Liebler-Tenorio, E. 2006.Lymphocytopathogenic activity in vitro correlates with high virulence in vivo for BVDV type 2 strains: Criteria for a third biotype of BVDV. Virus. Res. 118, 62-69.

19. Roberts, K.L, Collins, J.K, Carman, J, Blair, C.D. 1991 Detection of cattle infected with bovine viral diarrhea virus using nucleic acid hybridization. J Vet Diagn Invest. 3:10- 15.

20. Vilcek, S., Herring, A.J., Herring, J.A., Nettleton, P.F., Lowings, J.P., Paton, D.J., 1994. Pestiviruses isolated from pigs, cattle and sheep can be allocated into at least three genogroups using polymerase chain reaction and restriction endonuclease analysis. Arch. Virol. 136, 309-323.

21. Weinstock, D.; Bhudevi, B.; Castro, A.E. 2001 Single-tube single-enzyme reverse transcriptase PCR assay for detection of bovine viral diarrhea virus in pooled bovine serum. J ClinMicrobiol. ; 39(1):343-346. 